\title{
Antioxidant capacity and fatty acids characterization of heat treated cow and buffalo milk
}

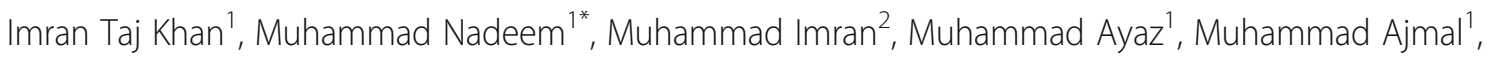
Muhammad Yaqoob Ellahi ${ }^{3}$ and Anjum Khalique ${ }^{4}$

\begin{abstract}
Background: Antioxidant capacity of milk is largely due to vitamins A, E, carotenoids, zinc, selenium, superoxide dismutase, catalase, glutathione peroxidase and enzyme systems. Cow milk has antioxidant capacity while the antioxidant capacity of buffalo milk has been studied in a limited way. The information regarding the effect of pasteurization and boiling on antioxidant capacity of cow and buffalo milk is also scared.
\end{abstract}

Methods: Cow and buffalo milk was exposed to two different heat treatments i.e. $65^{\circ} \mathrm{C}$ for 30 min and boiling for $1 \mathrm{~min}$. After heat treatments, milk samples were cooled down to $4^{\circ} \mathrm{C}$ packaged in transparent $250 \mathrm{ml}$ polyethylene PET bottles and stored at $4^{\circ} \mathrm{C}$ for 6 days. Milk composition, total flavonoid content, total antioxidant capacity, reducing power, DPPH free radical scavenging activity, antioxidant activity in linoleic acid, vitamin C, A, E, selenium, Zinc, fatty acid profile, peroxide value and sensory characteristics were studied in raw, pasteurized and boiled cow and buffalo milk at 0,3 and 6 days of storage period.

Results: Total antioxidant capacity (TAC) of raw, pasteurized and boiled milk for cow (42.1, 41.3 and 40.7\%) and buffalo (58.4, 57.6 and 56.5\%) samples was found, respectively. Reducing power (RP) of raw cow and buffalo milk was 6.74 and 13.7 while pasteurization and boiling did not showed significant effect on RP of both cow and buffalo milk. DPPH activity of raw, pasteurized and boiled milk for cow (24.3, 23.8 and 23.6\%) and buffalo (31.8, 31.5 and 30.4\%) samples was noted, respectively. Storage period up to 3 days was non-significant while DPPH assay after 6 days of storage period indicated significant decline in antioxidant activity of milk samples. Antioxidant activity in linoleic acid (AALA) of buffalo and cow milk were recorded 11.7 and $17.4 \%$, respectively. Pasteurization and boiling did not showed any impact on antioxidant capacity of cow and buffalo milk. The Loss of vitamin C in pasteurization (40 and 42\%) and boiling (82 and 61\%) of cow and buffalo milk was recorded, respectively. Concentration of vitamin A and $\mathrm{E}$ in pasteurized cow and buffalo milk was not significantly different from raw milk samples of cow and buffalo. Concentration of selenium and zinc was not influenced by the heat treatment in both cow and buffalo milk samples. After 3 days of refrigerated storage, antioxidant capacity of both cow and buffalo milk decreased. Concentrations of short-chain and medium-chain fatty acids increased in pasteurized and boiled cow and buffalo milk, while long-chain fatty acids decreased in pasteurized and boiled cow and buffalo milk, with no effect on colour and flavor score. Peroxide value of pasteurized and boiled cow and buffalo milk was not influenced by the storage up to 3 days.

Conclusions: These results suggest that buffalo milk had a higher antioxidant capacity than cow milk and pasteurized milk should be consumed within 3 days of refrigerated storage for better antioxidant perspectives.

Keywords: Heat treatment, Cow milk, Buffalo milk, Antioxidant capacity, Boiling, Pasteurization

\footnotetext{
* Correspondence: muhammad.nadeem@uvas.edu.pk

'Department of Dairy Technology, University of Veterinary and Animal

Sciences, Lahore, Punjab, Pakistan

Full list of author information is available at the end of the article
}

(c) The Author(s). 2017 Open Access This article is distributed under the terms of the Creative Commons Attribution 4.0 International License (http://creativecommons.org/licenses/by/4.0/), which permits unrestricted use, distribution, and reproduction in any medium, provided you give appropriate credit to the original author(s) and the source, provide a link to the Creative Commons license, and indicate if changes were made. The Creative Commons Public Domain Dedication waiver (http://creativecommons.org/publicdomain/zero/1.0/) applies to the data made available in this article, unless otherwise stated. 


\section{Background}

Buffalo milk is contributing $12 \%$ of the total milk production in the world. About $80 \%$ of total buffalo milk is produced in India and Pakistan [1]. In subcontinent, buffalo milk is preferred over cow milk due to white color, higher fat, protein, total solids contents and creamy taste [2]. Buffalo milk is highly suitable for the manufacturing of wide range of value added dairy products, such as, yoghurt, mozzarella and cheddar cheese [3]. Buffalo milk is healthier than cow milk in terms of lower concentration of cholesterol and higher magnitude of unsaturated fatty acids [4]. Fat content of buffalo and cow milk ranges from 6 to $7 \%$ and 3.5-4.5\%, respectively [5]. Protein content of buffalo and cow milk is $3.8-4 \%$ and $3.2-3.3 \%$, respectively while ash content of buffalo and cow milk is $0.82 \%$ and $0.72 \%$, respectively. The viscosity of buffalo milk is also greater than cow milk [6]. In addition to the normal nutritional perspectives, certain milk constituents have functional value. Antioxidants are chemical substances than scavenge/neutralize the free radicals and foods should contain enough concentration of antioxidants to prevent oxidative stresses. Uninterrupted reactive oxygen species can lead to diabetes, atherosclerosis, accelerated ageing, breakdown of DNA and several essential biochemical compounds [7]. Increased incidences of metabolic diseases have led the consumers to make healthy choices of foods and demand for functional foods is mounting across the world. Changing life styles have led the food industry and researchers to develop functional foods and determine the functional value of traditional foods. Increased knowledge in free radical biology has led the consumer to consume functional foods containing natural antioxidants. Casein, whey, sulphur containing amino acids, selenium, zinc, catalase, glutathione peroxidase, superoxide dismutase, vitamin E, C and beta-carotene has antioxidant activity in milk [8]. Concentration of vitamin $\mathrm{E}$ in buffalo and cow milk is 5.5 and $2.1 \mathrm{mg} /$ $100 \mathrm{ml}$, respectively while the amount of vitamin $\mathrm{C}$ in buffalo and cow milk is 3.66 and $0.94 \mathrm{mg} / 100 \mathrm{ml}$, respectively [9]. Buffalo milk has higher magnitude of sulfur containing amino acids, selenium and zinc as compared to cow milk [10]. Concentration of betacarotene in cow milk is more than buffalo milk. Due to the difference in the concentration of antioxidant substances, buffalo and cow milks may have different antioxidant capacity. Antioxidant capacity of few fermented dairy products is reported in literature. Antioxidant capacity of goat milk based kefir was investigated by 2-Diphenyl-1picrylhydrazyl assays and antioxidant capacity of kefir was more than native milk [11]. Antioxidant capacity of probiotic yoghurt was studied in cow, goat and camel milk using Pediococcus pentosaceus and it was observed that fermentation improved the antioxidant capacity of probiotic yoghurts [12]. Pasteurization is one of the most commonly used technique for the processing of fluid milk, in Pakistan, about $2-3 \%$ milk is pasteurized whereas, rest of the milk is boiled at homes for household applications. Effect of pasteurization and boiling on antioxidant characteristics of cow and buffalo milk should be studied for improved consumption patterns.

During pasteurization, milk is exposed to a certain heat treatment for a specific period of time and this time and temperature combination may have impact on antioxidant characteristics of milk. Similarly, storage time may also affect the antioxidant activity of milk and dairy products. Different heat treatments are performed to kill the pathogens in milk. Chemical composition of cheddar cheese is considerably different from parent milk [13]. Changes in antioxidant activity of pasteurized milk and cheddar cheese during pasteurization and ripening period are not previously discussed. Production of bioactive peptides during the ripening of cheddar cheese increased the antioxidant capacity of cheese [14]. However, effect of heat treatment and storage period on antioxidant characteristics of pasteurized milk from cow and buffalo milk is not previously investigated. Therefore, functional value of buffalo milk may be different from cow milk. Buffalo milk is widely used for the manufacturing of large number of value added dairy products and literature review evidenced that cow milk has antioxidant capacity, whereas, antioxidant capacity of buffalo milk is not previously studied. Detailed investigation on antioxidant perspectives of cow milk is also required for the better understanding of functional value of world's largest source of milk. In such a situation, functional value of traditional foods should be discovered. This study was planned to determine the antioxidant characteristics of cow and buffalo milk on the basis of some chemical characteristics.

\section{Methods}

Raw materials

Cow and Buffalo milk was obtained from Dairy Animals Training and Research Centre, University of Veterinary and Animal Sciences Lahore, Pakistan. All the chemicals used in this study were GC-grade and obtained from Sigma Chemical Co. (St. Louis, MO, USA).

\section{Experimental plan}

Cow and buffalo milk was exposed to two different heat treatments i.e. $65{ }^{\circ} \mathrm{C}$ for $30 \mathrm{~min}$ and boiling for $1 \mathrm{~min}$. After heat treatments, milk samples were cooled down to $4{ }^{\circ} \mathrm{C}$ packaged in $250 \mathrm{ml}$ polyethylene PET bottles and stored at $4{ }^{\circ} \mathrm{C}$ for 9 days.

Following antioxidant characteristics of heated treated milk were determined at 0,3 , and 6 days of storage period. 
Chemical composition of cow and buffalo milk

Milk composition of raw and heat treated cow and buffalo milk was determined on lactoscan (Julie Z7-Slovakia).

\section{Total flavonoid content}

Total flavonoid content in milk samples were determined by $\mathrm{AlCl}_{3}$ spectrophotometric assay using Rutin as standard. In a test tube, milk sample $(0.1 \mathrm{ml})$ was mixed with $0.2 \mathrm{ml}\left(5 \% \mathrm{NaNO}_{3}\right)$, after $5 \mathrm{~min} 0.2 \mathrm{ml} \mathrm{AlCl}_{3}$ and $1 \mathrm{ml} \mathrm{NaOH}$ (1 Molar) was added, contents were incubated for $15 \mathrm{~min}$ at room temperature. Absorbance of the samples and standards was measured at $510 \mathrm{~nm}$ on a double bean spectrophotometer (Shimadzu, Japan). Total flavonoid content was calculated from the calibration curve and reported as mg RE/g [15].

\section{Total antioxidant activity}

Total antioxidant activity in milk samples was determined according to the method of Nabasree and Bratati [16]. Sample $0.3 \mathrm{ml}$ was mixed with $3 \mathrm{ml}$ each of $0.6 \mathrm{M}$ sulfuric acid, $28 \mathrm{mM}$ sodium phosphate and $4 \mathrm{mM}$ ammonium molybdate). Test tubes were incubated at $85{ }^{\circ} \mathrm{C}$ for $90 \mathrm{~min}$, absorbance was recorded at $695 \mathrm{~nm}$ in visible region of spectrum using reagent blank and ascorbic acid solution as standard. Total antioxidant activity was reported as mg Ascorbic Acid Equivalent per gram.

\section{Reducing power}

Reducing power of the milk samples was determined by following the method of Adesegun et al. [17] by mixing $2.5 \mathrm{ml}$ sample with $2.5 \mathrm{ml}$ potassium ferricyanide (1\%), followed by incubation at $50{ }^{\circ} \mathrm{C}$ for $20 \mathrm{~min}$. After incubation, $2.5 \mathrm{ml}$ trichloroacetic acid solution (10\%) was added and centrifuged $1000 \times \mathrm{g}, 10 \mathrm{~min}$ ). Supernatant $2.5 \mathrm{ml}$ was mixed with same volume of deionized water and $0.5 \mathrm{ml}$ ferric chloride (0.1\%) was added. Absorbance was recorded at $700 \mathrm{~nm}$ on a double beam spectrophotometer.

\section{1,1-diphenyl-2-picrylhydrazyl (DPPH) free radical scavenging activity}

DPPH free radical scavenging activity was determined by the method [17]. $1 \mathrm{ml}$ milk samples were added with $1 \mathrm{ml}$ of methanol solution of DPPH $(1 \mathrm{mM})$, vortexed at $2200 \mathrm{rpm}$ for $1 \mathrm{~min}$ and incubated at room temperature for $20 \mathrm{~min}$, absorbance was recorded at $517 \mathrm{~nm}$ on a double bean spectrophotometer and DPPH free radical scavenging activity was reported in percentage.

\section{Antioxidant activity in linoleic acid system}

Antioxidant activity of milk samples in linoleic acid system was determined by the method prescribed by Osawa and Namiki [18]. Milk sample $0.5 \mathrm{ml}$ was mixed with $0.13 \mathrm{ml}$ linoleic acid solution in $99.8 \%$ ethanol and $10 \mathrm{ml}(0.2 \mathrm{M})$ sodium phosphate buffer, volume of mixture was diluted to $25 \mathrm{ml}$. Solutions were incubated at $40{ }^{\circ} \mathrm{C}$ and degree of oxidation was assessed by the thiocyanate method; $10 \mathrm{ml}$ ethanol (75\%), $0.2 \mathrm{ml}$ ammonium thiocyanate, $10 \mathrm{ml}$ ethanol (75\%) and $0.2 \mathrm{ml}$ ferrous chloride (20 mM in 3.5\% hydrochloric acid). After mixing for $3 \mathrm{~min}$, absorbance was measured at $500 \mathrm{~nm}$ on a double bean spectrophotometer and BHT was also used as positive control [19].

\section{Determination of vitamin $\mathrm{E}$}

Fat from milk was extracted by the standard method [20]. Concentration of Vitamin E in milk samples was determined on HPLC (Miford, MA; 715 Ultra WISP injector; $25 \mathrm{~cm} \times 4.6 \mathrm{~mm}$ diameter 5 - $\mu \mathrm{m}$ Supelcosil LC-Si; Supelco, Bellefonte, PA). $200 \mu \mathrm{g}$ milk fat was mixed with $2 \mathrm{ml}$-hexane (HPLC grade). The contents were vortexed at $1500 \mathrm{rpm}$ for $25 \mathrm{~s}$ and injected into HPLC. Mobile was comprised of $0.5 \%$ ethyl acetate and $0.5 \%$ acetic acid in hexane with flow rate adjusted at $1.5 \mathrm{ml} / \mathrm{min}$. Vitamin $\mathrm{E}$ was expressed as $\mu \mathrm{g} / \mathrm{g}[21]$.

\section{Determination of vitamin A}

For the determination of vitamin A in milk, $20 \mathrm{ml} \mathrm{milk}$ sample was added with $5 \mathrm{ml}$ ammonia (25\%) and $20 \mathrm{ml}$ ethanol (96\%). Supernatant was extracted and added with $0.0025 \%$ BHT. Solvent was evaporated at $35{ }^{\circ} \mathrm{C}$ on a rotary evaporator. Saponification was performed with $30 \mathrm{ml}$ potassium hydroxide (5\% in ethanol) followed by the extraction with $n$-hexane. Solvent was evaporated on rotary evaporator and $20 \mu \mathrm{l}$ injected into HPLC equipped with LC-20 AT pumping system, waters 990 detector and Spherisorb RP-18 column (Shimadzu). Retinyl palmitate was used as standard in various concentrations. Mobile phase was comprised of acetonitril-methanol 85:15 in isocratic system [22].

\section{Determination of vitamin C}

Vitamin C was determined by HPLC and for this purpose $300 \mu \mathrm{l}$ milk samples were mixed with $300 \mu \mathrm{l} 0.56 \%$ metaphosphoric acid, followed by centrifugation at $10{ }^{\circ} \mathrm{C}$ for $10 \mathrm{~min}$ at $3000 \times \mathrm{g}$. measurement was performed at $254 \mathrm{~nm}$ using ascorbic acid as standard. Quantification of vitamin $C$ was performed by calibration curve [23].

\section{Fatty acid profile}

Fatty acids profile was determined as fatty acid methyl esters developed from $300-\mu \mathrm{L}$ melted and well mixed sample. The sample was taken into 11-mL screw capped test tube, dissolved in $3-\mathrm{mL}$ isooctane and 2-mL $0.5 \mathrm{~N}$ sodium methoxide was added. The samples were vortexed at higher speed for exactly 3-min and allowed to separate for $5 \mathrm{~min}$. The supernatant was injected by auto sampler into Gas Chromatograph 7890-A Agilent, fitted with a methyl lignoserate-coated (film thickness $0.251 \mathrm{~m}$ ), SP-2330 
(SUP ELCO Inc. Supelco Park Bellefonte, PA 16823-0048, USA) polar capillary column $(30 \mathrm{~m} \times 0.32 \mathrm{~mm})$. Fatty acids were identified and quantified by FAME 37 internal standards $[24,25]$.

\section{Peroxide value}

Peroxide value in raw, pasteurized and boiled cow and buffalo milk was determined at 0,3 and 6 days of storage period according to the standard method [26].

\section{Determination of zinc and selenium}

Selenium and Zinc were determined by the standard methods [27].

\section{Statistical analysis}

Every sample was analyzed three times and the data were expressed as Mean \pm SD $(n=3 \times 3 ; \pm$ SD $n=3 \times 3)$. Data was analyzed by using two-way analysis of variance techniques to find out the effect of treatment and storage by using SAS 9.1 (Statistical Analysis Software) software. $P$-value of 0.05 and 0.01 was used to denote the significant and highly significant difference.

\section{Results and discussion}

Chemical composition of raw, pasteurized and boiled milk

Pasteurization and boiling did not have any effect on fat, protein, lactose, ash, solids not fat and total solids content (Table 1). Results of current investigation are not different from the earlier studies [10].

\section{Antioxidant characteristics of raw, pasteurized and boiled cow and buffalo milk Total flavonoid content (TFC)}

TFC of raw, pasteurized and boiled cow and buffalo milk are given in Table 2. Total flavonoid contents were expressed in Rutin Equivalent ( $\mathrm{mg} / \mathrm{ml})$. TFC in buffalo milk was greater than cow milk. TFC of cow and buffalo milk were not influenced by pasteurization and boiling operations. Results of earlier investigation have shown that TFC of harshly processed foods was less than initial value [28]. Total flavonoid content was also influenced by the storage period while storage period up to 3 days was non-significant. The concentration of total flavonoids in raw, pasteurized and boiled cow and buffalo milk decreased in 6 days old milk. Flavonoids are secreted in milk from fodder and feed and furthermore magnitude depends upon the concentration of flavonoids in feed stuff, therefore, their concentration may vary, as they are feed derived biochemical compounds. It may be assumed that they are usually present in milk, however, this aspect requires detailed investigation with respect to feed, breed and seasonal effects. Antioxidant properties of flavonoids are scientifically established [29]. Little is known regarding the existing of flavonoids in cow and buffalo milk.

\section{Total antioxidant capacity of cow and buffalo milk (TAC)}

TAC refers to the antioxidant status of biochemical compounds and measures the antioxidant response to counter the free radicals produced. TAC can be used as a novel marker for the assessment of oxidative stress [30]. TAC of buffalo milk was higher than cow milk, buffalo milk has higher concentration of vitamin $\mathrm{C}, \mathrm{E}$, selenium, zinc, tyrosine, cysteine, antioxidant activity of these chemical constituents is scientifically established. Catalase also possesses the antioxidant activity and catalase activity is 2-4 times higher in buffalo milk as compared to cow milk. This might be the justification for higher total antioxidant capacity of buffalo milk than cow milk. Pasteurization and boiling did not have any significant effect on TAC of cow and buffalo milk (Table 2). TAC of raw, pasteurized and boiled cow milk was 42.1, 41.3 and 40.7\%, respectively. TAC of raw, pasteurized and boiled buffalo milk was 58.4, 57.6 and 56.5\%, respectively. Zulueta et al. [31] stated that oxygen radical absorbance capacity of ultra high temperature treated milk and pasteurized milk was 13.17 and $13.93 \mu \mathrm{M}$ trolox equivalents $(p>0.05)$, respectively. Total antioxidant capacity of raw, pasteurized, boiled, cow and buffalo milk remain unchanged during the storage period of 3 days, however, total antioxidant capacity of 6 days old raw,

Table 1 Chemical composition of raw, pasteurized and boiled cow and buffalo milk

\begin{tabular}{|c|c|c|c|c|c|c|}
\hline \multirow[t]{2}{*}{ Parameter } & \multicolumn{3}{|l|}{ Cow Milk } & \multicolumn{3}{|l|}{ Buffalo Milk } \\
\hline & Raw Milk & Pasteurized & Boil & Raw Milk & Pasteurized & Boil \\
\hline Fat Content\% & $4.17 \pm 0.13^{b}$ & $4.14 \pm 0.05^{b}$ & $4.21 \pm 0.11^{b}$ & $6.45 \pm 0.16^{a}$ & $6.42 \pm 0.08^{a}$ & $6.53 \pm 0.07^{\mathrm{a}}$ \\
\hline Protein\% & $3.22 \pm 0.09^{b}$ & $3.19 \pm 0.03^{b}$ & $3.26 \pm 0.02^{b}$ & $3.82 \pm 0.14^{a}$ & $3.80 \pm 0.05^{a}$ & $3.88 \pm 0.12^{a}$ \\
\hline Lactose\% & $4.54 \pm 0.19^{b}$ & $4.52 \pm 0.23^{b}$ & $4.61 \pm 0.17^{b}$ & $4.85 \pm 0.26^{\mathrm{a}}$ & $4.87 \pm 0.12^{\mathrm{a}}$ & $4.94 \pm 0.25^{\mathrm{a}}$ \\
\hline Ash\% & $0.73 \pm 0.04^{b}$ & $0.72 \pm 0.02^{b}$ & $0.73 \pm 0.05^{b}$ & $0.83 \pm 0.01^{a}$ & $0.82 \pm 0.07^{\mathrm{a}}$ & $0.84 \pm 0.06^{a}$ \\
\hline SNF\% & $8.65 \pm 0.28^{a}$ & $8.58 \pm 0.09^{a}$ & $8.75 \pm 0.07^{\mathrm{a}}$ & $9.65 \pm 0.21^{a}$ & $9.61 \pm 0.15^{\mathrm{a}}$ & $9.81 \pm 0.32^{a}$ \\
\hline Total Solids\% & $12.7 \pm 0.34^{b}$ & $12.6 \pm 0.28^{b}$ & $12.9 \pm 0.30^{b}$ & $16.21 \pm 0.43^{a}$ & $16.05 \pm 0.24^{a}$ & $16.29 \pm 0.18^{a}$ \\
\hline
\end{tabular}

Within a row, means denoted by a different letter are statistically different $(P<0.05)$ 
Table 2 Antioxidant characteristics of raw, pasteurized and boiled cow and buffalo milk

\begin{tabular}{|c|c|c|c|c|c|c|c|}
\hline \multirow[t]{2}{*}{ Parameter } & \multirow[t]{2}{*}{ Days } & \multicolumn{3}{|l|}{ Cow Milk } & \multicolumn{3}{|l|}{ Buffalo Milk } \\
\hline & & Raw Milk & Pasteurized & Boil & Raw Milk & Pasteurize & Boil \\
\hline \multirow[t]{3}{*}{ TFC Rutin Equivalent mg/ml } & 0 & $1.89 \pm 0.04^{c}$ & $1.85 \pm 0.05^{c}$ & $1.82 \pm 0.12^{c}$ & $3.72 \pm 0.06^{a}$ & $3.71 \pm 0.14^{\mathrm{a}}$ & $3.68 \pm 0.07^{a}$ \\
\hline & 3 & $1.87 \pm 0.09^{c}$ & $1.84 \pm 0.11^{c}$ & $1.81 \pm 0.17^{c}$ & $3.68 \pm 0.02^{a}$ & $3.65 \pm 0.10^{a}$ & $3.63 \pm 0.03^{a}$ \\
\hline & 6 & $1.45 \pm 0.03^{d}$ & $1.42 \pm 0.02^{d}$ & $1.39 \pm 0.13^{d}$ & $3.41 \pm 0.07^{b}$ & $3.43 \pm 0.18^{b}$ & $3.37 \pm 0.02^{b}$ \\
\hline \multirow[t]{3}{*}{ TAC $\%$} & 0 & $42.1 \pm 1.58^{c}$ & $41.3 \pm 1.15^{c}$ & $40.7 \pm 0.94^{c}$ & $58.4 \pm 1.81^{a}$ & $57.6 \pm 1.47^{\mathrm{a}}$ & $56.5 \pm 1.62^{a}$ \\
\hline & 3 & $41.6 \pm 0.87^{c}$ & $39.9 \pm 1.61^{c}$ & $39.8 \pm 1.16^{c}$ & $56.8 \pm 1.21^{a}$ & $56.2 \pm 1.66^{a}$ & $55.7 \pm 1.84^{a}$ \\
\hline & 6 & $37.5 \pm 1.28^{d}$ & $38.4 \pm 0.79^{d}$ & $37.5 \pm 1.65^{d}$ & $52.7 \pm 1.37^{b}$ & $49.8 \pm 1.28^{b}$ & $47.4 \pm 0.73^{b}$ \\
\hline \multirow[t]{3}{*}{$\mathrm{RP}$} & 0 & $6.74 \pm 0.53^{c}$ & $6.63 \pm 0.71^{c}$ & $6.55 \pm 0.44^{c}$ & $13.7 \pm 1.19^{\mathrm{a}}$ & $13.5 \pm 0.93^{\mathrm{a}}$ & $13.4 \pm 0.55^{\mathrm{a}}$ \\
\hline & 3 & $6.51 \pm 0.38^{c}$ & $6.14 \pm 0.35^{c}$ & $5.87 \pm 0.62^{c}$ & $12.9 \pm 0.56^{\mathrm{a}}$ & $13.3 \pm 0 . .^{72 a}$ & $12.6 \pm 0.55^{a}$ \\
\hline & 6 & $5.3 \pm 0.62^{d}$ & $4.9 \pm 0.22^{d}$ & $4.77 \pm 0.35^{d}$ & $10.3 \pm 0.43^{b}$ & $11.6 \pm 0.31^{b}$ & $10.8 \pm 1.26^{b}$ \\
\hline \multirow[t]{3}{*}{ DPPH \% } & 0 & $24.3 \pm 0.49^{d}$ & $23.8 \pm 1.10^{c}$ & $23.6 \pm 0.58^{c}$ & $31.8 \pm 1.77^{\mathrm{a}}$ & $31.5 \pm 0.67^{a}$ & $30.4 \pm 0.94^{a}$ \\
\hline & 3 & $23.7 \pm 0.66^{d}$ & $23.1 \pm 1.53^{c}$ & $22.7 \pm 1.05^{\complement}$ & $30.6 \pm 1.49^{a}$ & $29.7 \pm 0.52^{a}$ & $29.5 \pm 0.45^{a}$ \\
\hline & 6 & $21.6 \pm 1.23^{\mathrm{e}}$ & $19.4 \pm 0.91^{\mathrm{e}}$ & $16.5 \pm 0.27^{e}$ & $28.6 \pm 0.84^{b}$ & $27.4 \pm 1.17^{b}$ & $26.7 \pm 1.22^{b}$ \\
\hline \multirow[t]{3}{*}{ AA in LA \% } & 0 & $11.7 \pm 0.39^{c}$ & $11.3 \pm 0.37^{c}$ & $11.1 \pm 0.44^{c}$ & $17.4 \pm 0.62^{a}$ & $17.1 \pm 1.13^{\mathrm{a}}$ & $16.8 \pm 0.98^{\mathrm{a}}$ \\
\hline & 3 & $11.2 \pm 0.44^{c}$ & $10.7 \pm 0.53^{c}$ & $9.11 \pm 0.19^{c}$ & $16.9 \pm 0.33^{a}$ & $13.7 \pm 0.70^{a}$ & $11.8 \pm 0.62^{\mathrm{a}}$ \\
\hline & 6 & $8.55 \pm 0.76^{d}$ & $8.76 \pm 0.27^{d}$ & $8.73 \pm 0.38^{d}$ & $15.8 \pm 1.37^{b}$ & $11.2 \pm 0.91^{b}$ & $10.4 \pm 0.36^{b}$ \\
\hline
\end{tabular}

Within the rows and columns of a parameter, means denoted by a different letter are statistically different $(P<0.05)$

TFC Total Flavonoid Content (mg Rutin/g)

TAC Total Antioxidant Capacity

$R P$ Reducing Power

$\mathrm{DPPH}$

$A A$ in LA Antioxidant Activity in Linoleic Acid

$\mathrm{H}_{2} \mathrm{O}_{2}$ FRSA Hydrogen Peroxide Free Radical Scavenging Activity

pasteurized and boiled cow and buffalo milk was significantly less than zero day. Jung et al. [32] mentioned that antioxidant capacity of the yoghurt fortified with red Ginseng extract decreased during the refrigeration storage. Jeong et al. [33] studied the impact of heat treatment on antioxidant capacity of citrus peels. Samples were exposed to 50,100 and $150{ }^{\circ} \mathrm{C}$ for $10,20,30,40,50$ and $60 \mathrm{~min}$. Antioxidant activity of citrus peel increased as the temperature and time increased.

\section{Reducing power (RP)}

RP of raw cow and buffalo milk was 6.74 and 13.7, respectively while pasteurization and boiling did not have significant effect on RP of both cow and buffalo milk. After pasteurization, RP of cow and buffalo milk decreased by $1.63 \%$ and $1.45 \%$, respectively from the raw milk samples. After boiling, RP of cow and buffalo milk decreased by $2.81 \%$ and $2.19 \%$, respectively from the raw milk samples. Greater reducing in raw, pasteurized and boiled buffalo milk may be attributed to the existence of higher concentration of antioxidant substances. Antioxidant characterization of buffalo milk revealed that it is healthier than cow milk. Reactive oxygen species can lead to the degeneration of cell membrane, protein mutilation, DNA mutation, cancers and cardiovascular diseases [34]. Recent dietary guidelines suggest including natural antioxidant in the diet to avoid oxidative stress.
In this regard, polyphenols such as flavonoids and phenolic acids have been found to have antioxidant properties [35]. Antioxidant capacity of milk and some fermented dairy products is described in literature. Antioxidant systems of milk can efficiently inhibit superoxide radicals, hydroxyl radicals and peroxide radicals (19, from antioxidant review paper). Ruiz de Gordoa et al. [36] studied the effect of grazing on antioxidant capacity of sheep milk, grazing enhanced the antioxidant capacity of milk. Roy and Deepak [37] reported that milk oligosaccharides have antioxidant capacity and they suggested detailed investigations to know their medicinal and functional value. Supplementation of ice cream with olein fraction of chia (Salvia hispanica L.) improved the free radical scavenging activity of ice cream [38].

\section{DPPH free radical scavenging activity}

Results of DPPH free radical scavenging activity of raw, pasteurized and boiled milk at 0,3 and 6 days of storage are described in Table 2. DPPH free radical scavenging activity of buffalo milk was higher than cow milk. Pasteurization and boiling did not have any significant effect on DPPH free radical scavenging of both cow and buffalo milk. DPPH free radical scavenging activity of raw, pasteurized and boiled cow milk was 24.3, 23.8 and $23.6 \%$, respectively, whereas, DPPH free radical scavenging activity of buffalo milk was $31.8,31.5$ and $30.4 \%$, 
respectively. Storage period up to 3 days was nonsignificant, DPPH assay after 6 days of storage period indicated significant decline in antioxidant activity of raw, pasteurized, boiled cow and buffalo milk. DPPH is one of the most commonly used assay for the determination of antioxidant capacity of dairy products. [39] Used $\mathrm{DPPH}$ free radical scavenging assay for the determination of antioxidant capacity of milk. DPPH free radical scavenging activity of yoghurt, acidophilus milk, butter milk and flavored fermented were compared, of the said dairy products, yoghurt revealed the highest antioxidant activity [40]. DPPH free radical scavenging activity of milk and goat milk kefir were compared and kefir revealed stronger antioxidant activity [11].

\section{Antioxidant Activity in Linoleic Acid (AALA).}

Results of free radical scavenging activity in linoleic acid of raw, pasteurized and boiled milk at 0,3 and 6 days of storage are presented in Table 2. AALA of buffalo milk was more than cow milk. AALA of buffalo and cow milk were $11.7 \%$ and $17.4 \%$, respectively. Pasteurization and boiling did not have any effect on AALA in both cow and buffalo milk. AALA of raw, pasteurized and boiled cow milk was $11.7 \%, 11.3 \%$ and $11.1 \%$, respectively. AALA of raw, pasteurized and boiled buffalo milk was $17.4 \%, 17.1 \%$ and $16.8 \%$, respectively. AALA of raw, pasteurized and boiled milk samples up to 3 days of storage period was not different from fresh samples (0 day). AALA of 6 days stored samples in refrigeration was considerably different from fresh samples in raw, pasteurized and boiled milk. AALA of dairy products has been reported in literature. Nadeem et al. [41] reported that supplementation of whey butter with almond peel extract improved the AALA. Supplementation of ice cream with sugarcane juice enhanced the AALA [38]. Fortification of Gouda cheese with mango kernel oil increased the antioxidant capacity of Gouda cheese [42]. Addition of interesterified Moringa oleifera oil in ice cream increased the antioxidant capacity [43]. Antioxidant capacity of probiotic yoghurt containing lactobacillus pentacoccus was higher than substrate milk [12]. Cow milk has antioxidant capacity, while antioxidant capacity of buffalo milk is not previously studied. In this pioneer study, detailed investigation has been done on antioxidant capacity of raw and thermally processed cow and buffalo milk.

\section{Effect of pasteurization and boiling on vitamin content of cow and buffalo milk}

Milk has two distinct antioxidant systems, fat soluble and water soluble antioxidant system. Fat soluble antioxidant system is mainly comprised of vitamin $\mathrm{A}$ and $\mathrm{E}$ and water soluble antioxidant is comprised of ascorbic acid and minerals. In current investigation, transition in concentration of vitamins and minerals of cow and buffalo as a function of pasteurization and boiling was used as an indication of change of antioxidant capacity at different stages of storage period. Results regarding influence of pasteurization and boiling on vitamins and minerals content of cow and buffalo milk are presented in Table 3. Amount of vitamin $\mathrm{C}$ in raw, pasteurized and boiled cow milk was $0.52,0.33$ and $0.09 \mathrm{mg} / 100 \mathrm{~g}$, respectively while Vitamin $C$ in raw, pasteurized and boiled buffalo milk was $0.68,0.39$ and $0.26 \mathrm{mg} / 100 \mathrm{~g}$, respectively. Loss of vitamin $C$ in pasteurization of cow and buffalo milk was $40 \%$ and $42 \%$, respectively. The loss of vitamin C in boiling of cow and buffalo milk was $82 \%$ and $61 \%$, respectively. Concentration of vitamin $\mathrm{A}$ and $\mathrm{E}$ in pasteurized cow and buffalo milk was not significantly different from raw milk samples of cow and buffalo. Storage period had a pronounced effect on concentration of vitamin $\mathrm{A}, \mathrm{E}$ and $\mathrm{C}$. Storage period up to 3 days was non-significant. Vitamin A and $\mathrm{E}$ content of boiled cow and buffalo milk samples were significantly less than raw milk samples. Concentration of vitamin $\mathrm{A}$ and $\mathrm{E}$ and raw and pasteurized milk was not different [44]. Michlova et al. [45] described that concentration of vitamin A during thermal processing and storage period decreased. Saffert et al. [46] studied the effect of UHT treatment and storage period on vitamin A content and UHT treatment and storage period considerably affected vitamin C. All the determination frequencies revealed the decreasing trend during the 12 weeks of storage period. Vitamin $\mathrm{E}$ is a powerful antioxidant than vitamin $\mathrm{A}$, concentration of vitamin $\mathrm{E}$ also decreased during thermal processing and storage of milk [47]. Effect of heat treatment on vitamins of milk is extensively studied however, little information is available regarding the transition of antioxidant capacity of milk with respect to alteration in vitamin A, E and C. Total antioxidant capacity of cow and buffalo milk were strongly correlated with vitamin A at 0,3 and 6 days of storage period. Results of selenium and zinc content of raw, pasteurized and boiled cow milk are presented in Table 3. Selenium and zinc contents of buffalo milk were greater than cow milk. Selenium and zinc content of both cow and buffalo milk were not influenced by pasteurization, boiling and storage period of 6 days. Selenium is a trace mineral that is essential, recommended dietary allowance for selenium is $50 \mu \mathrm{g} /$ day [48]. Antioxidant capacity of selenium is reported in literature, selenium intake reduced the risk of heart disease, cystic fibrosis and cancer [49]. $\mathrm{Zn}$ is one of the most significant water soluble antioxidant of milk and essential trace mineral, recommended dietary allowance of $\mathrm{Zn}$ is $15 \mathrm{mg} /$ day and use of selenium for the fortification of Turkish white cheese has been reported [50].

\section{Fatty acid profile of cow and buffalo milk}

Results regarding fatty acid profile of raw, pasteurized and boiled cow and buffalo milk are given in Table 4. Fatty acid profiles of raw cow milk were different from raw buffalo 
Table 3 Vitamin and mineral content of raw, pasteurized and boiled cow and buffalo milk

\begin{tabular}{|c|c|c|c|c|c|c|c|}
\hline \multirow[t]{2}{*}{ Parameter } & \multirow[t]{2}{*}{ Days } & \multicolumn{3}{|l|}{ Cow Milk } & \multicolumn{3}{|l|}{ Buffalo Milk } \\
\hline & & Raw Milk & Pasteurized & Boil & Raw Milk & Pasteurize & Boil \\
\hline \multirow{3}{*}{$\begin{array}{l}\text { Vitamin C } \\
\mathrm{mg} / 100 \mathrm{~g}\end{array}$} & 0 & $0.52 \pm 0.03^{b}$ & $0.31 \pm 0.06^{d}$ & $0.09 \pm 0.01^{9}$ & $0.68 \pm 0.07^{\mathrm{a}}$ & $0.39 \pm 0.04^{c}$ & $0.26 \pm 0.05^{\mathrm{e}}$ \\
\hline & 3 & $0.41 \pm 0.02^{c}$ & $0.27 \pm 0.01^{\mathrm{e}}$ & $0.07 \pm 0.02^{9}$ & $0.53 \pm 0.09^{b}$ & $0.33 \pm 0.02^{d}$ & $0.23 \pm 0.03^{e}$ \\
\hline & 6 & $0.30 \pm 0.05^{d}$ & $0.19 \pm 0.02^{f}$ & $0.03 \pm 0.01^{h}$ & $0.38 \pm 0.10^{c}$ & $0.21 \pm 0.06^{f}$ & $0.11 \pm 0.01^{9}$ \\
\hline \multirow{3}{*}{$\begin{array}{l}\text { Vitamin A } \\
\mu \mathrm{g} / 100 \mathrm{~g}\end{array}$} & 0 & $62.8 \pm 1.57^{c}$ & $58.9 \pm 1.36^{\mathrm{cd}}$ & $51.2 \pm 0.76^{d}$ & $131.9 \pm 2.45^{\mathrm{a}}$ & $129.7 \pm 1.17^{\mathrm{a}}$ & $128.8 \pm 1.31^{\mathrm{a}}$ \\
\hline & 3 & $64.5 \pm 2.51^{c}$ & $55.7 \pm 2.61^{c d}$ & $49.71 \pm 0.95^{d}$ & $128.9 \pm 3.67^{a}$ & $127.8 \pm 1.42^{\mathrm{a}}$ & $128.5 \pm 1.72^{\mathrm{a}}$ \\
\hline & 6 & $47.2 \pm 0.88^{d}$ & $37.5 \pm 0.53^{\mathrm{e}}$ & $28.44 \pm 1.08^{f}$ & $105.73 \pm 1.22^{b}$ & $106.58 \pm 1.64^{b}$ & $103.2 \pm 0.98^{\mathrm{b}}$ \\
\hline \multirow{3}{*}{$\begin{array}{l}\text { aTocopherol } \\
\mathrm{mg} / 100 \mathrm{~g}\end{array}$} & 0 & $0.19 \pm 0.01^{c}$ & $0.17 \pm 0.02^{c}$ & $0.15 \pm 0.01^{c}$ & $1.27 \pm 0.15^{\mathrm{a}}$ & $1.21 \pm 0.13^{\mathrm{a}}$ & $1.19 \pm 0.08^{\mathrm{a}}$ \\
\hline & 3 & $0.16 \pm 0.03^{c}$ & $0.14 \pm 0.01^{c}$ & $0.12 \pm 0.02^{c}$ & $1.23 \pm 0.09^{a}$ & $1.16 \pm 0.03^{\mathrm{a}}$ & $1.15 \pm 0.02^{\mathrm{a}}$ \\
\hline & 6 & $0.09 \pm 0.04^{d}$ & $0.08 \pm 0.03^{d}$ & $0.06 \pm 0.01^{d}$ & $0.97 \pm 0.05^{b}$ & $0.95 \pm 0.14^{b}$ & $0.92 \pm 0.07^{b}$ \\
\hline \multirow{3}{*}{$\begin{array}{l}\text { Selenium } \\
\mu \mathrm{g} / 100 \mathrm{~g}\end{array}$} & 0 & $0.92 \pm 0.13^{b}$ & $0.94 \pm 0.16^{b}$ & $0.91 \pm 0.11^{b}$ & $6.22 \pm 0.10^{\mathrm{a}}$ & $6.25 \pm 0.32^{\mathrm{a}}$ & $6.18 \pm 0.32^{\mathrm{a}}$ \\
\hline & 3 & $0.91 \pm 0.08^{b}$ & $0.88 \pm 0.05^{b}$ & $0.88 \pm 0.03^{b}$ & $6.12 \pm 0.13^{a}$ & $6.20 \pm 0.19^{a}$ & $6.14 \pm 0.03^{\mathrm{a}}$ \\
\hline & 6 & $0.88 \pm 0.15^{b}$ & $0.84 \pm 0.04^{b}$ & $0.86 \pm 0.02^{b}$ & $6.11 \pm 0.06^{\mathrm{a}}$ & $6.13 \pm 0.07^{a}$ & $6.11 \pm 0.14^{\mathrm{a}}$ \\
\hline \multirow{3}{*}{$\begin{array}{l}\text { Zinc } \\
\mu \mathrm{g} / 100 \mathrm{~g}\end{array}$} & 0 & $419.7 \pm 4.39^{b}$ & $417.3 \pm 3.94^{b}$ & $412.9 \pm 3.89^{b}$ & $563.5 \pm 7.56^{\mathrm{a}}$ & $559.3 \pm 2.43^{\mathrm{a}}$ & $554.6 \pm 3.97^{a}$ \\
\hline & 3 & $416.5 \pm 5.41^{b}$ & $415.6 \pm 4.22^{b}$ & $408.7 \pm 2.55^{b}$ & $559.7 \pm 11.2^{a}$ & $554.4 \pm 6.82^{\mathrm{a}}$ & $549.3 \pm 7.21^{\mathrm{a}}$ \\
\hline & 6 & $411.8 \pm 7.49^{b}$ & $413.4 \pm 9.27^{b}$ & $403.5 \pm 6.77^{b}$ & $552.6 \pm 9.73^{a}$ & $550.2 \pm 8.52^{a}$ & $542.1 \pm 2.88^{\mathrm{a}}$ \\
\hline
\end{tabular}

Within the rows and columns of a parameter, means denoted by a different letter are statistically different $(P<0.05)$

Table 4 Effect of pasteurization and boiling on fatty acid profile of cow and buffalo milk ( $\mathrm{g} / 100 \mathrm{~g})$

\begin{tabular}{|c|c|c|c|c|c|c|c|}
\hline \multirow{2}{*}{$\begin{array}{l}\text { Fatty } \\
\text { Acid }\end{array}$} & \multirow[t]{2}{*}{ Day } & \multicolumn{3}{|l|}{ Cow Milk } & \multicolumn{3}{|l|}{ Buffalo Milk } \\
\hline & & Raw & Pasteurized & Boil & Raw & Pasteurized & Boil \\
\hline \multirow[t]{2}{*}{$\overline{C_{4: 0}}$} & 0 & $3.75 \pm 0.04^{b}$ & $3.82 \pm 0.03^{b}$ & $3.94 \pm 0.05^{\mathrm{a}}$ & $3.98 \pm 0.09^{\mathrm{a}}$ & $4.11 \pm 0.08^{\mathrm{a}}$ & $4.33 \pm 0.09^{a}$ \\
\hline & 6 & $3.58 \pm 0.13^{c}$ & $3.79 \pm 0.02^{b}$ & $3.81 \pm 0.07^{b}$ & $3.88 \pm 0.13^{b}$ & $3.95 \pm 0.11^{b}$ & $4.15 \pm 0.07^{b}$ \\
\hline \multirow[t]{2}{*}{$C_{6: 0}$} & 0 & $2.28 \pm 0.07^{j}$ & $2.87 \pm 0.16^{f}$ & $3.35 \pm 0.17^{d}$ & $2.41 \pm 0.13^{h}$ & $3.96 \pm 0.21^{b}$ & $4.19 \pm 0.14^{\mathrm{a}}$ \\
\hline & 6 & $2.21 \pm 0.08^{k}$ & $2.71 \pm 0.03^{9}$ & $3.26 \pm 0.08^{\mathrm{e}}$ & $2.32 \pm 0.05^{i}$ & $3.61 \pm 0.09^{c}$ & $4.03 \pm 0.06^{b}$ \\
\hline \multirow[t]{2}{*}{$C_{8: 0}$} & 0 & $1.53 \pm 0.02^{i}$ & $1.68 \pm 0.08^{h}$ & $1.92 \pm 0.16^{9}$ & $2.53 \pm 0.17^{e}$ & $2.81 \pm 0.19^{c}$ & $3.35 \pm 0.22^{\mathrm{a}}$ \\
\hline & 6 & $1.71 \pm 0.05^{h}$ & $1.91 \pm 0.03^{9}$ & $2.56 \pm 0.04^{e}$ & $2.39 \pm 0.29^{f}$ & $2.71 \pm 0.12^{d}$ & $3.19 \pm 0.16^{b}$ \\
\hline \multirow[t]{2}{*}{$C_{10: 0}$} & 0 & $3.42 \pm 0.03^{9}$ & $3.98 \pm 0.05^{h}$ & $5.22 \pm 0.43^{b}$ & $3.67 \pm 0.11^{f}$ & $4.23 \pm 0.06^{d}$ & $5.42 \pm 0.07^{\mathrm{a}}$ \\
\hline & 6 & $3.32 \pm 0.31^{h}$ & $3.73 \pm 0.15^{i}$ & $4.89 \pm 0.27^{c}$ & $3.48 \pm 0.13^{9}$ & $3.97 \pm 0.03^{\mathrm{e}}$ & $5.27 \pm 0.02^{b}$ \\
\hline \multirow[t]{2}{*}{$C_{12: 0}$} & 0 & $4.25 \pm 0.06^{9}$ & $5.34 \pm 0.20^{e}$ & $6.55 \pm 0.18^{b}$ & $3.15 \pm 0.19^{i}$ & $5.33 \pm 0.14^{e}$ & $6.86 \pm 0.21^{a}$ \\
\hline & 6 & $4.11 \pm 0.26^{h}$ & $5.15 \pm 0.38^{f}$ & $6.38 \pm 0.41^{c}$ & $3.03 \pm 0.04^{j}$ & $5.11 \pm 0.05^{f}$ & $5.66 \pm 0.07^{d}$ \\
\hline \multirow[t]{2}{*}{$C_{14: 0}$} & 0 & $11.68 \pm 0.29^{i}$ & $12.87 \pm 0.49^{e}$ & $14.59 \pm 0.67^{a}$ & $10.72 \pm 0.08^{k}$ & $12.19 \pm 0.53^{f}$ & $13.45 \pm 0.72^{c}$ \\
\hline & 6 & $11.15 \pm 0.62^{j}$ & $11.12 \pm 0.36^{h}$ & $14.11 \pm 0.43^{b}$ & $10.13 \pm 0.92^{1}$ & $11.66 \pm 0.83^{9}$ & $12.47 \pm 0.27^{d}$ \\
\hline \multirow[t]{2}{*}{$C_{16: 0}$} & 0 & $29.16 \pm 0.67^{g}$ & $31.45 \pm 1.24^{d}$ & $34.61 \pm 1.65^{\mathrm{a}}$ & $27.88 \pm 0.94^{j}$ & $29.82 \pm 1.44^{f}$ & $32.95 \pm 1.87^{b}$ \\
\hline & 6 & $28.72 \pm 0.99^{h}$ & $30.83 \pm 1.15^{\mathrm{e}}$ & $32.76 \pm 1.38^{b}$ & $25.41 \pm 1.55^{i}$ & $27.55 \pm 1.67^{j}$ & $31.44 \pm 0.94^{c}$ \\
\hline \multirow[t]{2}{*}{$C_{18: 0}$} & 0 & $9.35 \pm 0.38^{d}$ & $9.21 \pm 0.73^{d}$ & $9.13 \pm 0.52^{\mathrm{e}}$ & $12.77 \pm 0.33^{\mathrm{a}}$ & $11.24 \pm 0.53^{c}$ & $9.37 \pm 0.19^{d}$ \\
\hline & 6 & $9.17 \pm 0.46^{\mathrm{e}}$ & $8.83 \pm 0.42^{f}$ & $8.67 \pm 0.38^{9}$ & $12.05 \pm 0.66^{b}$ & $10.41 \pm 0.45^{c}$ & $8.62 \pm 0.32^{9}$ \\
\hline \multirow[t]{2}{*}{$C_{18: 1}$} & 0 & $21.18 \pm 0.97^{f}$ & $19.23 \pm 1.77^{h}$ & $18.66 \pm 0.54^{i}$ & $27.65 \pm 0.73^{a}$ & $26.39 \pm 1.14^{b}$ & $25.12 \pm 1.19^{c}$ \\
\hline & 6 & $20.06 \pm 0.97^{9}$ & $18.34 \pm 0.85^{i}$ & $17.92 \pm 0.46^{j}$ & $26.18 \pm 0.65^{b}$ & $24.59 \pm 1.35^{d}$ & $23.44 \pm 0.33^{\mathrm{e}}$ \\
\hline \multirow[t]{2}{*}{$C_{18: 2}$} & 0 & $1.98 \pm 0.05^{d}$ & $1.72 \pm 0.03^{e}$ & $1.37 \pm 0.21^{h}$ & $2.37 \pm 0.16^{\mathrm{a}}$ & $2.21 \pm 0.13^{b}$ & $1.91 \pm 0.16^{d}$ \\
\hline & 6 & $1.56 \pm 0.08^{9}$ & $1.62 \pm 0.11^{f}$ & $1.19 \pm 0.06^{i}$ & $2.12 \pm 0.13^{c}$ & $1.92 \pm 0.03^{d}$ & $1.51 \pm 0.13^{9}$ \\
\hline \multirow[t]{2}{*}{$C_{18: 3}$} & 0 & $0.48 \pm 0.02^{b}$ & $0.35 \pm 0.04^{d}$ & $0.22 \pm 0.05^{\mathrm{e}}$ & $0.64 \pm 0.01^{\mathrm{a}}$ & $0.55 \pm 0.08^{b}$ & $0.43 \pm 0.06^{c}$ \\
\hline & 6 & $0.27 \pm 0.03^{d}$ & $0.19 \pm 0.01^{e}$ & $0.13 \pm 0.02^{f}$ & $0.52 \pm 0.03^{b}$ & $0.44 \pm 0.02^{c}$ & $0.31 \pm 0.02^{d}$ \\
\hline
\end{tabular}


Table 5 Effect of pasteurization and boiling on peroxide value of cow and buffalo milk

\begin{tabular}{|c|c|c|c|c|c|c|}
\hline \multirow[t]{2}{*}{ Day } & \multicolumn{3}{|l|}{ Cow Milk } & \multicolumn{3}{|l|}{ Buffalo Milk } \\
\hline & Raw & Pasteurized & Boil & Raw & Pasteurized & Boil \\
\hline 0 & $0.22 \pm 0.02^{c}$ & $0.27 \pm 0.05^{c}$ & $0.39 \pm 0.07^{b}$ & $0.24 \pm 0.13^{c}$ & $0.29 \pm 0.05^{c}$ & $0.37 \pm 0.12^{b}$ \\
\hline 3 & $0.25 \pm 0.01^{c}$ & $0.30 \pm 0.06^{c}$ & $0.43 \pm 0.05^{b}$ & $0.26 \pm 0.09^{c}$ & $0.30 \pm 0.08^{\mathrm{a}}$ & $0.42 \pm 0.04^{b}$ \\
\hline 6 & $0.37 \pm 0.04^{b}$ & $0.41 \pm 0.03^{b}$ & $0.48 \pm 0.11^{\mathrm{a}}$ & $0.31 \pm 0.06^{c}$ & $0.37 \pm 0.10^{b}$ & $0.51 \pm 0.07^{a}$ \\
\hline
\end{tabular}

Within the rows and columns, means denoted by a different letter are statistically different $(P<0.05)$

milk. Concentration of short-chain fatty acids $\left(\mathrm{C}_{4: 0}\right.$ to $\left.\mathrm{C}_{10: 0}\right)$ in raw cow and buffalo milk was $10.98 \%$ and $15.59 \%$, respectively. Medium-chain fatty acids $\left(\mathrm{C}_{12: 0}\right.$ to $\left.\mathrm{C}_{16: 0}\right)$ in raw cow and buffalo milk were $45.09 \%$ and $41.09 \%$, respectively. Long-chain unsaturated fatty acids $\left(C_{18: 1}\right.$ to $\left.C_{18: 3}\right)$ in raw cow and buffalo milk were $23.64 \%$ and $30.66 \%$, respectively. Fatty acid profile of buffalo milk is different from cow milk [51]. Concentration of oleic acid in buffalo milk was $27.62 \% . C_{18: 1}$ content in buffalo milk was $29.47 \%$ [52]. Nadeem et al. [29] reported that concentration of $C_{18: 1}$ and $\mathrm{C}_{18: 2}$ in cow milk were $23.5 \%$ and $1.37 \%$, respectively. Pasteurization and boiling increased the concentration of short-chain fatty acids in both cow and buffalo milk. In pasteurized cow and buffalo milk, concentration of shortchain fatty acids was $12.35 \%$ and $15.11 \%$, respectively. In boiled cow and buffalo milk, concentration of short-chain fatty acids was $14.43 \%$ and $17.29 \%$, respectively. As a function of heat treatment, long-chain fatty acids may be converted into short-chain and medium-chain fatty acids [53]. Wang et al. [54] reported that concentration of short-chain and medium chain fatty acids increased after pasteurization of goat milk. Both cow and buffalo milk contains reasonable amount of $\mathrm{C}_{18: 1}$, unsaturated fatty acids play an important in human health. $\mathrm{C}_{18: 1}$. Fats rich in mono unsaturated fatty acids are getting a great deal of attention for having healthful properties and better oxidative stability. Monounsaturated fatty acids possess the capability of reducing blood cholesterol. $\mathrm{C}_{18: 2}$ and $\mathrm{C}_{18: 3}$ can decrease the serum cholesterol and essential fatty acids having major role in childhood development [55]. Fatty acid profile of raw, pasteurized and boiled cow and buffalo milk was also influenced by the storage period. The storage period up to 3 days was non-significant $(p>0.05)$, after this period, concentration of saturated and unsaturated fatty acids significantly decreased from the initial vale. Determination of fatty acid profile provides useful indication of oxidation status of milk and dairy products during processing and storage conditions, because accelerated oxidation conditions are usually not used for milk and dairy products. Fatty acid profile of processed and unprocessed goat milk was not similar to each other [56].

\section{Peroxide value}

Effects of pasteurization, boiling and storage period on peroxide value of raw, pasteurized and boiled cow and buffalo milk are described in Table 5 . Peroxide value of pasteurized and boiled cow and buffalo milk samples was greater than raw milk samples of cow and buffalo. Peroxide value of raw, pasteurized and boiled cow milk was $0.22,0.27$ and $0.39\left(\mathrm{MeqO}_{2} / \mathrm{kg}\right)$, respectively. Peroxide value of raw, pasteurized and boiled buffalo milk was 0.24 , 0.29 and $0.37\left(\mathrm{MeqO}_{2} / \mathrm{kg}\right)$, respectively. Peroxide value of raw, pasteurized and boiled cow and buffalo milk was not significant up to 3 days of refrigeration storage, determination of peroxide value after 6 days of storage period revealed significant difference from fresh and 3 days old samples of both cow and buffalo milk. The significant rise in peroxide value of raw and thermally processed cow and buffalo milk may be due to the decrease in antioxidant capacity, results of peroxide value and antioxidant capacity of 6 days stored cow and buffalo milk were in line with each other. The rise in peroxide value of cow milk as a function of pasteurization and boiling is reported in literature. Mashref et al. [57] studied the impact of pasteurization and boiling on peroxide value of cow milk and peroxide value of pasteurized and boiled milk

Table 6 Effect of pasteurization and boiling on sensory characteristics of cow and buffalo milk

\begin{tabular}{|c|c|c|c|c|c|c|c|}
\hline \multirow[t]{2}{*}{ Parameter } & \multirow[t]{2}{*}{ Day } & \multicolumn{3}{|l|}{ Cow Milk } & \multicolumn{3}{|l|}{ Buffalo Milk } \\
\hline & & Raw & Pasteurized & Boil & Raw & Pasteurized & Boil \\
\hline \multirow[t]{3}{*}{ Color } & 0 & $7.5 \pm 0.55^{b}$ & $7.4 \pm 0.42^{b}$ & $7.4 \pm 0.09^{b}$ & $8.1 \pm 0.39^{a}$ & $8.0 \pm 0.15^{a}$ & $8.2 \pm 0.27^{a}$ \\
\hline & 3 & $7.4 \pm 0.40^{b}$ & $7.3 \pm 0.48^{b}$ & $7.2 \pm 0.26^{b}$ & $8.0 \pm 0.14^{a}$ & $7.9 \pm 0.11^{\mathrm{a}}$ & $8.1 \pm 0.22^{\mathrm{a}}$ \\
\hline & 6 & $7.1 \pm 0.23^{c}$ & $6.8 \pm 0.37^{d}$ & $6.7 \pm 0.30^{d}$ & $7.5 \pm 0.24^{b}$ & $7.4 \pm 0.13^{b}$ & $7.3 \pm 0.19^{b}$ \\
\hline \multirow[t]{3}{*}{ Flavor } & 0 & Not Determined & $7.5 \pm 0.40^{b}$ & $7.5 \pm 0.06^{b}$ & Not Determined & $8.2 \pm 0.07^{a}$ & $8.0 \pm 0.19^{\mathrm{a}}$ \\
\hline & 3 & & $7.3 \pm 0.28^{b}$ & $7.4 \pm 0.08^{b}$ & & $8.0 \pm 0.17^{a}$ & $7.8 \pm 0.11^{\mathrm{a}}$ \\
\hline & 6 & & $6.9 \pm 0.18^{c}$ & $7.0 \pm 0.08^{c}$ & & $7.5 \pm 0.38^{b}$ & $7.6 \pm 0.26^{b}$ \\
\hline
\end{tabular}

Within the rows and columns, means denoted by a different letter are statistically different $(P<0.05)$ 
was greater than raw milk. Peroxide value of cow milk increased during the storage period of 6 days [29]. However, the oxidative stability of buffalo milk is not studied in detail.

\section{Sensory evaluation}

Effect of pasteurization and storage period of 6 days on colour and flavour of cow and buffalo milk is described in Table 6. Colour of raw buffalo milk was white and raw cow milk was slightly yellowish. Pasteurization and boiling did not have any effect on colour and flavour score of both cow and buffalo milk. Higher colour and flavour score of all the three version of buffalo milk was due to the taste preference of buffalo milk in the subcontinent. Storage period up to 3 days was non-significant in raw, pasteurized and boiled cow and buffalo milk. After 3 days of storage, colour and flavour score was remarkably decreased $(p<0.05)$.

\section{Conclusions}

The results of the present study concluded that Antioxidant capacity of buffalo milk was more than cow milk while pasteurization and boiling did not any effect on antioxidant capacity, vitamin E, A, zinc, selenium and sensory characteristics of cow and buffalo milk. Antioxidant capacity of buffalo and cow milk decreased after 3 days of refrigerated storage. These results suggest that buffalo milk has more health prospects than cow milk.

\section{Acknowledgements}

The authors are highly obliged to the Library Department, Government College University Faisalabad (GCUF), University of Veterinary and Animal Sciences (UVAS) and IT Department, Higher Education Commission (HEC, Islamabad) for access to journals, books and valuable database.

\section{Funding}

Financial assistance for this study was provided by Higher Education Commission of Pakistan.

\section{Availability of data and materials}

The dataset supporting the conclusions of this article is included within the article.

\section{Authors' contributions}

ITK performed the research work as PhD fellow; MN guided in research as supervisor; MI, MA, MA, MYE, AK helped to analyse the data and drafting the manuscript. "It's also confirmed that all the authors read and approved the final manuscript".

\section{Ethics approval and consent to participate}

Not applicable.

\section{Consent for publication}

Not applicable.

\section{Competing interests}

The authors declare that they have no competing interests.

\section{Publisher's Note}

Springer Nature remains neutral with regard to jurisdictional claims in published maps and institutional affiliations.

\section{Author details}

'Department of Dairy Technology, University of Veterinary and Animal Sciences, Lahore, Punjab, Pakistan. ${ }^{2}$ Institute of Home and Food Sciences, Faculty of Science and Technology, Government College University, Faisalabad, Punjab, Pakistan. ${ }^{3}$ Army College of Veterinary Sciences, Sargodha, Punjab, Pakistan. ${ }^{4}$ Department of Animal Nutrition, University of Veterinary and Animal Sciences, Lahore, Punjab, Pakistan.

Received: 20 April 2017 Accepted: 21 August 2017

Published online: 24 August 2017

\section{References}

1. Mahmood A, Sumaira U. A comparative study on the physico-chemical parameters of milk samples collected from buffalo, cow, goat and sheep of Gujrat, Pakistan. Pak J Nut. 2010;9(12):1192-7.

2. Bilal MQ, Suleman M, Raziq A. Buffalo: black gold of Pakistan. Livestock Res Rural Dev. 2006;18(9):1-15.

3. Ahmad S, Anjum FM, Huma N, Sameen A, Zahoor T. Composition and physico-chemical characteristics of buffalo milk with particular emphasis on lipids, proteins, minerals, enzymes and vitamins. J Anim PI Sci. 2013;23:62-74

4. Talpur FN, Memon NN, Bhanger MI. Comparison of fatty acid and cholesterol content of Pakistani water buffalo breeds. Pak J Anal Environ Chem. 2007:8:15-20.

5. Abbas HM, Hassan FAM, Abd El-Gawad MAM, Enab AK. Physicochemical characteristics of goat's milk. Life Sci J. 2014;11(1):307-17.

6. Mahmood A, Usman S. A comparative study on the physicochemical parameters of milk samples collected from buffalo, cow, goat and sheep of Gujarat Pakistan. Asian network for scientific information. Pak J of Nutr. 2010;9(12):1192-7.

7. Kris-Etherton PM, Hecker KD, Bonanome A, Coval SM, Binkoski AE, Hilpert KF, Griel $A E$, Etherton TD. Bioactive compounds in foods: their role in prevention of cardiovascular disease and cancer. Am J Med. 2002;113:71-88.

8. Usta B, Yilmaz-Ersan L. Antioxidant enzymes of milk and their biological effects. J Agric Fac Uludag Univ. 2013;27(2):123-30.

9. Humma N, Sameen A, Zahoor T, Anjum M. Composition and physico-chemical characteristics of buffalo milk with particular emphasis on lipids, proteins, minerals, enzymes and vitamins. J Animal and Plant Sci. 2013;23:62-74.

10. Ahmad S, Gaucher I, Rousseau F, Beaucher E, Piot M, Grongnet JF, Gaucheron F. Effects of acidification on physico-chemical characteristics of buffalo milk: a comparison with cow's milk. Food Chem. 2008;106:11-7.

11. Yilmaz-Ersan L, Ozcan T, Akpinar-Bayizit A, Sahin S. The antioxidative capacity of kefir produced from goat milk. Int J Chem Eng Appl. 2016;7(1): 22-6.

12. Balakrishnan G, Agrawal R. Antioxidant activity and fatty acid profile of fermented milk prepared by Pediococcus pentosaceus. J Food Sci Technol. 2012;51(12):4138-42.

13. Murtaza MA, Rehman SU, Anjum FM, Huma N, Tarar OM, Mueen-Ud-Din G. Organic acid contents of buffalo milk cheddar cheese as influenced by accelerated ripening and sodium salt. J Food Biochem. 2011; DOI:10.1111/j. 1745-4514.2010.00517

14. Rashidinejad A, Birch EJ, Everett DW. Antioxidant activity and recovery of green tea catechins in full-fat cheese following gastrointestinal simulated digestion. J Food Comp Anal. 2016;48:13-24.

15. Nile $\mathrm{SH}$, Khobragade CN. Antioxidant activity and flavonoid derivatives of Plumbago Zeylanica. J Nat Products. 2010;3:130-3.

16. Nabasree D, Bratati D. Antioxidant activity of some leafy vegetables of India: a comparative study. Food Chem. 2007;101:471-4.

17. Adesegun SA, Elechi NA, Coker HAB. Antioxidant activities of methanolic extract of Sapium elliticum. Pak J Biol Sci. 2008;11:453-7.

18. Osawa T, Namiki M. A novel type of antioxidant isolated from leaf wax of eucalyptus leaves. Agric Biol Chem. 1981;45(3):735-9.

19. Yen GC, Duh PD, Tsai CL. Relationship between antioxidant activity and maturity of peanut hulls. J Agric Food Chem. 1993;41:67-70.

20. AOAC. Official Methods of Analysis. 16th ed. Gaithersburg: Association of Official Analytical Chemists, AOAC Internat; 1997.

21. Jang $S, X u Z$ Z. Lipophilic and hydrophilic antioxidants and their antioxidant activities in purple rice bran. J Agric Food Chem. 2009;57:858-62.

22. Pece A, Pintea A, Bele C, Muresan G, O'Coroian C. Determination of Vitamin A from Buffalo Milk Using HPLC Method. Opatija Croatia: 43rd Croatian and 3rd International Symposium on Agriculture; 2014. p. 763-5. 
23. Romeu-nadal M, Morera-Pons S, Castellote Al, Lopez-Sabater MC. Rapid high performance liquid chromatographic method for vitamin C determination in human milk versus an enzymatic method. J Chromatography. 2006;830:41-6.

24. Qian SY, Yue GH, Tomer KB, Mason RP. Identification of all classes of spintrapped carbon-centered radicals in soybean lipoxygenase-dependent lipid peroxidations of omega- 6 polyunsaturated fatty acids via LC/ESR, LC/MS, and tandem MS. Free Rad Biol Med. 2003;34:1017-28.

25. IUPAC. Standard Methods for the Analysis of Oils, Fats and Derivatives. 7th ed. Oxford: IUPAC, Applied Chem Division, Commission on Oils and Fats Derivatives, Blackwell Scientific Publications; 1987.

26. AOCS. Official Methods of Analysis of AOCS. 4th ed. Method Cd 8-53. Official Methods and Recommended practices of the American Oil Chemists Society, 4th ed. AOCS, Champaign, IL, USA. 1995.

27. Larmond E. Laboratory Methods for Sensory Evaluation of Foods. Ottawa Publications, Canada: Reasearch Branch, Department of Agriculture; 1987. p. 153-6.

28. Zhang MW, Zhang RF, Zhang FX, Liu RH. Phenolic pro- files and antioxidant activity of black rice bran of different commercially available varieties. J Agric Food Chem. 2010;58:7580-7.

29. Nadeem M, Abdullah M, Khalique A, Hussain I, Mahmud A, Inayat S. The effect of Moringa Oleifera leaf extract as antioxidant on stabilization of butter oil with modified fatty acid profile. J Agric Sci Tech. 2013;15:919-28.

30. Sies H. Total antioxidant capacity: appraisal of a concept. J of Nutr. 2007;137:1493-5.

31. Zulueta A, Esteve MJ, Frigola A. ORAC and TEAC assays comparison to measure the antioxidant capacity of food products. Food Chem. 2009; 114(1):310-6.

32. Jung J, Paik HD, Yoon HJ, Jang HJ, Jeewanthi RKC, Jee HC, Li X, Lee NK, Lee SK. Physicochemical Characteristics and Antioxidant Capacity in Yogurt Fortified with Red Ginseng Extract. Korean J Food Sci An. 2016;3:412-20.

33. Jeong SM, Kim SY, Kim DR, Jo SC, Nam KC, Ahn DU, Lee SC. Effect of heat treatment on the antioxidant activity of extracts from citrus peels. J Agric Food Chem. 2004;52:3389-93.

34. Liao KL, Yin MC. Individual and combined antioxidant effects of seven phenolic agents in human erythrocyte membrane ghosts and phosphatidylcholine liposome systems: importance of the partition coefficient. J Agric Food Chem. 2000;48:2266-70.

35. Gil MI, Ferreres F, Tomas-Barberan FA. Effect of post harvest storage and processing on the antioxidant constituents (Flavonoids and vitamin C) of fresh-cut spinach. J Agric Food Chem. 1999;47:2213-7.

36. Ruiz de Gordoa JC, Bustamante M, Arranz J, Virto M, Barrón LJR, Beltrán de Heredia I, Amores G, Abilleira E, Nájera Al, Ruiz R, Albisu M, Pérez-Elortondo FJ, Mandaluniz N. Increase in water-soluble total antioxidant capacity of sheep's milk as a result of increased grazing time. Options Méditerr. 2011;99: 267-71.

37. Roy T, Deepak D. Antioxidant properties of milk oligosaccharides from various ruminants. Int J Pharm Bio Sci. 2014;5(2):400-8.

38. Ullah R, Nadeem M, Imran M. Omega-3 fatty acids and oxidative stability of ice cream supplemented with olein fraction of chia (Salvia hispanical.) oil. Lipids Health Dis. 2017, 16:34.

39. Smet K, Raes K, De Block J, Herman L, Dewettinck K, Coudijzer K. A change in antioxidative capacity as a measure of onset to oxidation in pasteurized milk. Int Dairy J. 2008;18:520-30.

40. Najgebauer-Lejko D, Sady M. Estimation of the antioxidant activity of the commercially available fermented milks. Acta Sci Pol Technol Aliment. 2015; 14(4):387-96.

41. Nadeem M, Mahmud A, Imran M, Khalique A. Enhancement of the oxidative stability of whey butter through almond (Prunis dulcis) peel extract. J Food Proc Preserv. 2014; doi:10.1111/jfpp.12265

42. Nadeem M, Imran M, Khalique A. Promising features of mango (Mangifera indica L.) kernel oil: a review. J Food Sci Technol. 2016;53(5):2185-95.

43. Nadeem M, Ulla R, Ullah A. Improvement of the physical and oxidative stability characteristics of ice cream through interesterified Moringa oleifera oil. Pak J Scienti Ind Res Ser B: Biol Sci. 2016;59(1):38-43.

44. Ohlsson T, Bengtsson N. Minimal processing of food with nonthermal methods. In: Ohlsson T, Bengtsson N, editors. Minimal Processing Technologies in the Food Industry. Cambridge: Woodhead Publishing; 2002. p. 34-60.

45. Michlova T, Dragounova H, Hornickova S, Heitmankova A. Factors influencing the content of vitamins $A$ and $E$ in sheep and goat milk. Czech J of Food Sci. 2015;33(1):58-65.
46. Saffert A, Pieper G, Jetten J. Effect of package light transmittance on the vitamin content of milk, Part 3: Fortified UHT Low-Fat Milk. Packaging technology and science Packag Technol. Science. 2002;22:31-7. 2009

47. Gauna C, Meyler FM, Janssen J, Delhanty PJD, Abribat T, Koetsveld P, Hofland J, Broglio F, Ghigo E, Lely AJ. Administration of acylated ghrelin reduces insulin sensitivity, whereas the combination of acylated plus unacylated grelin strongly improves insulin sensitivity. J Clini Endocrinol Metabolism. 2004;89:5035-42.

48. Fennema OR. Food chemistry. 3rd ed. New York: Marcel Dekker; 1996.

49. Tapiero H, Townsend DM, Tew KD. Phytosterols in the prevention of human pathologies. Biomed Pharmacother. 2003:57:321-5.

50. Gulbas SY, Saldamli I. The effect of selenium and zinc fortification on the quality of Turkish white cheese. Interna J Food Sci Nutrin. 2005;56(2):141-6.

51. Ménard O, Ahmad S, Rousseau F. Buffalo vs. cow milk fat globules: size distribution, zeta-potential, compositions in total fatty acids and in polar lipids from milk fat globule membrane. Food Chem. 2010;120:544-51.

52. Qureshi MS, Mushtaq A, Khan S. Variation in milk fatty acid composition with body condition in dairy buffaloes (Bubalusbubalis). Asian-Aust J Animal Sci. 2010:340-6.

53. McSweeny PLH, Fox PF. Advanced dairy chemistry, Proteins. 3rd ed. NY, USA: Kluwer Academic Plenum Pub.; 2003.

54. Wang $Y, Y u R$, Chou C. Antioxidative activities of soymilk fermented with lactic acid bacteria and bifidobacteria. Food Microbiol. 2006;23:128-35.

55. Corbett $P$. It is time for an oil change! Opportunities for high-oleic vegetables oils. Inform. 2003;14:480-1.

56. Sumarmono J, Sulistyowati M, Soenarto. Fatty acids profiles of fresh milk, yogurt and concentrated yogurt from Peranakan Etawah goat milk. Procedia Food Sci. 2015;3:216-22.

57. Mashref A. Al-Rowaily. Effect of heating treatments, processing methods and refrigerated storage of milk and some dairy products and lipid oxidation. Pakistan J Nutr. 2008;7(1):118-25.

\section{Submit your next manuscript to BioMed Central and we will help you at every step:}

- We accept pre-submission inquiries

- Our selector tool helps you to find the most relevant journal

- We provide round the clock customer support

- Convenient online submission

- Thorough peer review

- Inclusion in PubMed and all major indexing services

- Maximum visibility for your research

Submit your manuscript at www.biomedcentral.com/submit
C Biomed Central 